Buor, D.

Water needs and women's health in the Kumasi metropolitan area, Ghana.

Health \& Place: 10, 2004, nr. 1, p. 85-103

\begin{tabular}{|l|l|}
\hline Postprint Version & 1.0 \\
\hline Journal website & $\underline{\text { http://www.sciencedirect.com/science/journal/13538292 }}$ \\
\hline Pubmed link & $\begin{array}{l}\text { http://www.ncbi.nlm.nih.gov/entrez/query.fcgi?cmd=Retrieve\&db=pubmed\&dop } \\
\text { t=Abstract\&list_uids=14637289\&query_hl=31\&itool=pubmed_docsum }\end{array}$ \\
\hline DOI & $\underline{\underline{10.1016 / S 1353-8292(03) 00050-9}}$ \\
\hline
\end{tabular}

\title{
Water needs and women's health in the Kumasi metropolitan area, Ghana
}

\section{DANIEL BUOR*}

Geography Section, Faculty of Social Sciences, Kwame Nkrumah University of Science and

Technology, Kumasi, Ghana

*Tel.: +233-051-60182; fax: +233-051-60137.

E-mail address: danielbuor@yahoo.com (D. Buor).

\begin{abstract}
This paper examines the impact of water fetching by women and the quality of water during periods of water scarcity on the health of women in the Kumasi metropolitan area. A sample of 210 women drawn using systematic random procedure is used for the study. Formal interview is the main instrument used. The survey has established that income, quality of water, hours spent fetching water during scarcity and age are the main factors influencing women's health in the metropolis during water scarcity. In both the core and periphery, the water-related problem influencing health is hours spent fetching water during scarcity. An empirical model on water needs and women's health has emerged from the survey. Recommendations have been made on strategies to ensure regular volume of surface water, effective management of scarce water resources with the participation of women, and ensuring gender equity in domestic services.
\end{abstract}

\section{INTRODUCTION AND THE PROBLEM}

This study examines the health effects of water scarcity on women in the Kumasi metropolitan area, the second largest urban centre in Ghana. Water needs have had serious socio-economic and health effects in urban environments in developing countries where population concentrations have put a serious strain on available resources. Globally, as population grows, the quantity of water per capita decreases. In 1989 there were about $9000 \mathrm{~m}^{3}$ of freshwater per person available for human use (Clarke, 1991; Lean and Henrichsen, 1994). By 2000, because of the population growth, that amount dropped to about $7800 \mathrm{~m}^{3}$ (Gleick, 2000). The current accelerated urbanisation of developing countries is assessed as a consequence of rapidly growing population and rural poverty (United Nations (UN)/ Economic Commission for Africa, ECA, 1992). Developing countries are heading towards a situation where the carrying capacity of the urban areas is deteriorating due to growing populations that do not correspond with the rate at which resources are provided.

The growth of primate cities in Africa is worsening in its environmental plight. Among the serious environmental problems are waste accumulation and lack of adequate and safe water supply (Benneh, 1992). The accumulation of waste and the disposal problem has led to the streams being the receptacles of such waste, leading to their pollution and gradual extinction. A major factor of the water problem is wastage. Pipelines are regularly faulty, resulting in wastage of treated water. In the study area, Kumasi metropolitan area, this is a regular problem, especially at the periphery where there are illegal pipe connections, compounding the water-supply problem.

The water and sanitation problem in the Ashanti Region where the study area is located is such that WATERAID, a UK International organisation that supports deprived communities to gain access to 
Buor, D.

Water needs and women's health in the Kumasi metropolitan area, Ghana.

Health \& Place: 10, 2004, nr. 1, p. 85-103

safe water and sanitation, has selected it among three regions in Ghana to benefit from an earmarked six hundred thousand pounds $(£ 600,000)$ project to provide water and sanitation facilities for deprived communities for 2001 (Daily Graphic, 2001).

Polluted air, insufficient and unclean water are some of the sources of infection in Africa and most developing countries. In fact, clean and sufficient water would be the key to addressing most of the health problems in Africa. Biological, physical and chemical agents in the human environment cause or contribute to millions of premature deaths and to the ill health and disablement of hundreds of millions (Sloof, 1992). Such disease agents are mostly carried in water and the air.

Water-borne diseases, also known as "dirty water" diseases, are a result of using water contaminated by human, animal or chemical wastes. These diseases cause an estimated 12 million deaths a year, 5 million of them from diarrhoea-associated diseases. Most of the victims are children in developing countries (Davidson et al., 1992; United Nations, 1997). Polluted water is the source of viral hepatitis, cholera, leptospirosis, typhoid fever, amoebiasis, schistosomiasis, dracunculiasis, echinococcosis, malaria and onchocerciasis (Feachem et al., 1986a, b). Incidentally, some of these diseases have also been reported in the metropolis. Human faeces can contain pathogenic micro-organisms that can cause cholera, typhoid fever and dysentery (Mader, 1993). The health burden of unsafe and insufficient quantities of water and inadequate sanitation services has also been found to present itself in high rates of trachoma (Koos et al., 1995).

In the current environmental pandemic in Africa, concomitant deterioration is evidenced in the scarcity and impurity of water; the burden of ensuring the supply of this crucial commodity rests largely on women. The women also bear the burden of providing for domestic fuel needs. Cleaver (1991) succinctly summarises the burden of women in a deteriorating environment, thus:

Women's roles - to bear and rear children, to maintain the household, in part by collecting water and wood for fuel, and often to take primary responsibility for producing food crops - also link together issues of population, agriculture and the environment.

Ardayfio-Schandorf and Kwafo-Akoto (1990) also note that, in the Ghanaian society, the productive and reproductive roles of women are intricately dependent on environmental resources such as land, water and forest resources. Water and sanitation projects have tended to be targeted towards them (International Water and Sanitation Centre, IRC, 1995a, b). Research conducted in the Arusha region in Tanzania in 1994/ 1995 found that, in 75 per cent of the households interviewed, water collection was the responsibility of women and girls. About 13 per cent of boys fetched water, whilst only 9 per cent of men (fathers) were involved, and males were only involved where distances to the water sources were too great (UNDP, 1995). UNICEF, 1991 estimated maternal deaths in Tanzania at 200400 deaths per year, and they linked these deaths to women's heavy workload during the last 3 months of pregnancy. Water fetching by women and the possible effect on their health confirms the health and welfare consequences for women, who have been found to have higher morbidity than men (Anderson and Andersen, 1972; Kohn and White, 1978; Verbrugge, 1979; Cleary et al., 1982).

In several areas of the Third World, and especially in Ghana, culture dictates that the women take on most of the domestic roles. Domestic services are believed to be insignificant, so are consigned to women whose main functions, as defined by culture, are to reproduce and take care of children and the home. The predominance of the female domestic role depends upon the structure of authority, which is heavily weighted in favour of men (Nukunya, 1992).

Lloyd (1992) reported, in a research on family and gender issues for population policy, that, in developing countries, existing cultural pressures define women's role as principally that of wives and mothers. Saunders and Warford (1976) also found that the provision of water for the family in rural areas of most developing countries is the primary responsibility of women and children. This is also the trend in urban areas.

Large family sizes increase the water need, hence, the burden of water supply. In the event of water scarcity, traditional women would give priority to their husbands. They would ensure that their husbands' water needs were met before satisfying their own. It follows therefore that women are more likely to suffer the consequences of water scarcity.

The problems caused by water scarcity directly affect women's health, income and education. In a keynote address delivered by Chandni (2000) at the Second World Water Forum, he emphasised that 
water has an impact on women's health, education, employment, income and empowerment. His conclusions were based on the results of a United Nations Development Fund for Women (UNIFEM) project. Poverty, on the other hand, affects the ability of women to use preventive services and their access to health insurance (Holly et al., 2001). The water problem and women's development thus attracts the attention of international development organisations.

The burden imposed on women in the fetching of water, the general scarcity of water, and poor water quality in the Kumasi metropolitan area could be assessed by means of a thorough investigation. The problem is likely to affect women's health. Moreover, water scarcity creates poverty, which has implications for the health of women, apart from the direct health effects that result from the energy expended through water fetching and the use of polluted water. A conceptual model based on "water and women's health" is emerging from the analysis, and this paper will elucidate the relationship through hypothesis testing, in a spatial perspective, using appropriate statistical models.

The study is guided by four hypotheses. First, water fetching and water quality are the main factors producing ill health in women in the Kumasi metropolitan area during water scarcity. Second, metropolitan periphery suffers more from the effects of water fetching and water quality during water scarcity. Third, women's poverty is related to access to clean and adequate water supply in the Kumasi metropolitan area. Therefore, women's health is also related to their income.

\section{OBJECTIVES}

The objectives of the survey are fourfold, namely to,

(a) Assess the impact of poor water quality and the burden of water fetching on the health of women in the metropolitan area and by place of residence within the metropolis, i.e. urban core and urban periphery.

(b) Examine the relationship between water scarcity and the health of women by education and income.

(c) Examine the relative influence of water scarcity compared with the demographic and socioeconomic factors that influence women's health.

(d) Structure a conceptual model on water and women's health.

(e) Suggest strategies for ensuring sustainable water supply and limiting the burden of women in the provision of water supply.

\section{METHODS}

\section{The study area}

The study is a cross-sectional survey, which seeks to establish the relationship between water supply and women's health. The study area, Kumasi metropolitan area which is the fastest expanding metropolis in the Ashanti Region, was chosen for the survey (Fig. 1). It is a centre of diverse culture and commerce, and indeed reflects the socio-economic scenarios of the country. In Ghana, the family system is matrilineal, and the extended family system predominates. Though there is a significant inroad of Western culture, the status of women is still subordinate to men, and men take major family decisions. Even among educated elite families where there seems to be some female autonomy, men have a slight edge over the women in household decisions; and, domestic service, including water supply, is primarily the responsibility of women.

\section{[ FIGURE 1 ]}

\section{Sample selection and data collection}

A sample of 210 females aged 12 and above selected from settlements from the urban core and urban periphery (Fig. 2) was used for the survey. The sample comprises 90 from the urban core, and 120 from the urban periphery. There were two settlements chosen from the urban core, Bantama and Asafo, with a sample of 45 from each; and four from the urban periphery, Appiadu, Denkyemuoso, Nyankyerenease and Anwomaso, with 30 from each. The interview schedule, using a formal 
Buor, D.

Water needs and women's health in the Kumasi metropolitan area, Ghana.

Health \& Place: 10, 2004, nr. 1, p. 85-103

questionnaire, was the main research instrument. In addition to the respondents, the distribution engineer and principal hydrologist of the Ghana Water Company in Kumasi were interviewed.

\section{[ FIGURE 2 ]}

Systematic random sampling technique was used for the selection of respondents. For the urban core where there is greater concentration and number of housing units, the sample interval was 6; and, for the peripheral settlements which have less concentration of housing units, 4 . Each settlement was divided into a number of zones, and a zone randomly selected for the drawing of the sample.

In all, 14 persons did not agree to participate on the grounds that such interviews had not brought any change in the socio-economic development of the metropolis. A few were suspicious about the intentions of the survey, thinking that it was a means of assessing income for possible taxation. The non-response, however, would not affect the results of the survey, since substitutes of equal status were found.

\section{The variables}

The independent variables used for the entire survey were age, marital status, employment status, educational status, number of children, income, time spent on water fetching during regular flow and scarcity, regular source of water supply, daily water need, met daily water need during water scarcity, general health status, average net weekly income of entrepreneurs and traders during regular flow and scarcity, whilst the dependent variable was health status during water scarcity. Age is a determinant of health status as some health problems are correlated with it. Educational status of women has been found to exhibit a positive correlation with health and health-care use; whilst family size is likely to have an impact on the health of women, as the more children a woman has, the less healthy she is likely to be, in an environment dominated by poverty. Income is a strong determinant of health, affecting the ability to use health services, access to nutrition and decent housing. The time spent in fetching water imposes a serious strain on health, especially if it involves sacrificing sleeping hours, as it is in the metropolis for women who bear the burden of fetching water for their families.

Measurements of the economic impact of water supply have tended to include the time spent in fetching water and water use by women (IRC, 1995b, p. 27). The time and energy spent in water collection as a percentage of the total available daytime energy has also been used as a quantitative approach (Feachem et al., 1986a, b, p. 81). The quantity and quality of water supply also has health implications. For the regression model, the following key independent variables were initially selected: age, income, education, hours spent fetching water during scarcity, number of children, water quality, employment and proportion of water needs met during water scarcity.

\section{MEASURES}

For purposes of correlation and regression analyses, age, daily water need, number of children, time spent fetching water, and income were entered as continuous variables, whilst education, sources of water supply and health status were entered as ranked variables. Marital and employment status were entered as dichotomous variables. Educational status was ranked from " 1 " to " 4 "; " 1 " " being the "never-been-to school", " 2 " for "basic education", " 3 " for secondary education" and " 4 " for "tertiary education". Marital status was ranked as " 0 " for unmarried and " 1 " for married. The divorced, widowed and separated were considered in the unmarried category. The source of water supply were ranked " 1 " to " 5 ", as " 1 " for stream, " 2 " for hand-dug well, " 3 " for rain water, " 4 ", for borehole and " 5 " for treated pipe borne. The ranking followed a quality gradient. Health status was ranked based upon the frequency of sickness, being " 1 " for once in 2 weeks, " 2 " for once a month, " 3 " for once in 3 months, and " 4 " for rarely. Age was categorised by reproductive status for the purpose of cross-tabulating with the quantity used. Females of less than 14 years who had attained puberty were categorised into one group, whilst those between 14 and 49 years were in another category. The third category consisted of women of 50 years and over. Field survey revealed the average age for menstruation to be 14, and 49 for women who had reached menopause. This reproductive categorisation was based on the assumption that women need more water during their 
Buor, D.

Water needs and women's health in the Kumasi metropolitan area, Ghana.

Health \& Place: 10, 2004, nr. 1, p. 85-103

menstrual period, and, especially, for post-natal hygiene. At this stage they are also more cautious about personal hygiene and sanitation that requires a lot of water.

\section{Data analysis}

Data were analysed quantitatively using bivariate (Pearson's) correlation and multiple regression. A $p$ value equal to or less than $0.05(\leq 0.05)$ was used to determine significant variables. The two-tailed significance was used for the analysis. The levels of significance between the centre and periphery, based on $\chi^{2}$, are indicated for each variable.

The multiple regression model was preceded by correlation analysis to show the association among the variables. A multiple regression model was structured for the following selected independent variables: age, employment, education, income, number of children, water quality (source of water supply), hours spent in fetching water during scarcity, and proportion of water supplied during scarcity. Net weekly income was not entered into the regression model because it involved only a smaller proportion of the sample, i.e. traders and small-scale entrepreneurs.

\section{POPULATION GROWTH AND WATER SUPPLY}

The rate of the metropolitan population growth has been quite significant. The growth pattern is indicated in Table 1. The significant increases in the metropolitan population are due to high fertility, lower mortality, and cultural, administrative, industrial, commercial and migratory factors. First, Total Fertility Rate (TFR) is high, especially at the metropolitan margins and slums. Even though the national TFR is 4.6 (Ghana Statistical Service, GSS, 1999), it could be as high as 6 or even more among the predominantly illiterate. This is against the background of declining death rate with improvement in health facilities and nutrition. The other source of population growth is migration from the rural and semi-urban areas due to poor socio-economic facilities and low-income opportunities.

\section{[ TABLE 1 ]}

The status of the water supply in the metropolis does not match the demand for the range of domestic, sanitary, religious and industrial activities, with the evergrowing population. The main sources of water supply are the pipe-borne, stream and hand-dug wells. The metropolis largely depends on piped water. Wells and boreholes are found at its edges. Because of the watersupply problem, landlords, putting up houses on the metropolitan edges, drill boreholes. Harvested rainwater, which is used mainly for cooking, bathing and washing when there is no scarcity, is also a reliable source during the rainy season.

The main sources of pipe-borne water are the Barekese and Owabi dams (Fig. 3). The safe yields of the two dams supply water to the metropolis. Expected daily supply, and the actual daily supply are indicated in Table 2 . The expected daily yield of both dams constitutes only $34.3 \%$ of the safe yields. This is due to the low pumping capacity of the existing pumping machines that need to be replaced by more sophisticated ones with greater pumping capacity. The actual daily supply is $67,500 \mathrm{~m}^{3}$, constituting about $85.7 \%$ of the expected daily supply. The daily demand for water in the metropolis is $94,500 \mathrm{~m}^{3}$. Thus, the daily demand supplied is $71.4 \%$, indicating a shortfall of $28.6 \%$.

\section{[ FIGURE 3 ]}

\section{[TABLE 2 ]}

The demand situation is aggravated during the dry season by several factors. First, the drought situation causes increased consumption of water, in view of loss from excessive perspiration. Second, streams that are used to supplement pipe water are dry, aggravating the supply situation. Third, the production of dust that accompanies drought creates a situation where a lot of water is needed for cleaning to maintain environmental sanitation. Fourth, treated water is used to water vegetable and flower gardens in homes and compounds. Fifth, the construction industry also draws on treated water rather than streams and rainwater for its activities. 
Buor, D.

Water needs and women's health in the Kumasi metropolitan area, Ghana.

Health \& Place: 10, 2004, nr. 1, p. 85-103

There is acute demand during the dry season when there is a reduction in the water volume of the dam. Recently, there has been an increasing decline in the volume of the Barekese dam whose maximum depth stood at 8.0m in 1990 (Water Resources Research Institute, WRRI, 1990). The main cause of the decline is encroachment on the land bordering the dam. The watersheds of the dammed streams are being cleared of vegetation for farming and construction. The government has, however, taken aggressive measures to reverse the trend by protecting the dam area from further encroachment.

The quality of the two dams, with regard to the $\mathrm{pH}$ value, falls within the prescribed values of the WHO maximum permissible level of 6.5-8.5. The $\mathrm{pH}$ value for Barekese dam is 6.36-7.08, whilst that of Owabi dam is 6.42-7.22. Chemicals are used to treat the water for any bacterial and physicochemical pollution. The same cannot be said of boreholes, which are subject to fluoride pollution. The problem for streams in the metropolis is even worse. They are almost extinct through pollution by industrial, agricultural and municipal wastes. The $\mathrm{pH}$ value, alkalinity and DO (dissolved oxygen) levels, total water hardness and bacteria infection are such that they are completely unfit for human use. With an increasing population and for such supplementary sources rendered unusable, the watersupply problem is aggravated, especially, during the dry season. The situation is compounded by the encroachment by people on the forest area within the catchment areas for the dams that are the main sources of water supply. Government eviction orders to stop the encroachment have resulted in several court actions.

\section{RESULTS}

\section{Distribution of study variables}

The sample was made up of women aged 12 and above including schoolchildren, homemakers, traders and small-scale entrepreneurs. Appendix A presents the distribution of the sample across the selected variables for total sample and place of residence (core or periphery). Whereas percentages are reported for all the category variables, means and/or standard deviations are reported for the continuous variables. The largest number of women of marriageable age is married. The unemployment rate appears very high, apparently because of the large sample of school children, students and homemakers. Differences between age, marital status and employment status by place of residence are not significant. Educational level is quite low, with those who have not received secondary education constituting over $66 \%$ of total sample. The difference by place of residence is significant, and a central location means a higher level of education than a peripheral location. The husband's education does not differ significantly between the core and periphery. Average income reflects the national average. The daily minimum wage is just above $\$ 1$. The core enjoys higher incomes than the periphery and the difference by place of residence is significant. The average family size of 3.1 is about minimum, compared with the national total fertility rate of 4.6 (GSS, 1999). There is no significant difference by place of residence. Although over $56 \%$ of respondents have regular access to treated water, the number using streams and hand-dug wells, $35.6 \%$, is quite large. The exposure of hand-dug wells to pollution makes them unwholesome for human consumption, so could be as bad as streams, which over $18 \%$ use regularly.

The difference of water quality used by place of residence is quite significant. The core has greater access to quality water than the periphery. Hours spent fetching water during scarcity are over and above those spent during regular flow. Whereas the average is $0.76 \mathrm{~h}$ for regular flow, it is $2.5 \mathrm{~h}$ for periods of scarcity, and the difference in the number of hours for fetching water between the core and periphery during scarcity is not significant. The shortfall in water supply during periods of scarcity reflects in the incomes gained by small-scale entrepreneurs and traders. For periods with regular flow of water, the average net weekly income through their operations is eighty thousand eight hundred and forty seven Cedis, sixty-two Pesewas ( $\$ 80847.62)$; whilst during scarcity, it is sixty thousand and seven hundred and forty-two Cedis, eighty-six Pesewas ( $\Varangle 60742.86)$. The small-scale entrepreneurs use water for their operations, whilst the traders lose several hours of their trading activities in fetching water. On the issue of health, the general health status of respondents is better during regular flow than during scarcity. Whereas only $4.8 \%$ of respondents fall sick every 2 weeks during regular water supply, it is $24.6 \%$ for periods of scarcity. Difference in health status by place of residence during water scarcity is significant. The core enjoys better health than the periphery during this period. 
Buor, D.

Water needs and women's health in the Kumasi metropolitan area, Ghana.

Health \& Place: 10, 2004, nr. 1, p. 85-103

\section{Distribution of water use}

Water use by age/reproductive status, marital status, number of children, place of residence and by gender has been analysed to find the source of real stress on women due to water needs. The gender disparity has been assessed by the quantity of water used by the families that is used by husbands, whilst the other variables have been examined and their differences established by probability values, using $\chi^{2}$. Daily water needs and proportions obtained during periods of scarcity, especially during the dry season, ${ }^{1}$ have been analysed.

The water needs of the aged are more than the young (Table 3). Respondents who have not menstruated use water far less than those who are in the reproductive age group. However, the proposition that the aged who do not experience the monthly cycle need less water has not been validated. The possible causes may be family size and marital status. There is a clear dichotomy in water need and use by marital status and number of children (family size) (Tables 4 and 5). The married need far greater amount of water than the unmarried, since they are more likely to have large family sizes; and, also, since they must cater for the water requirements of their husbands. The statistics also show that number of children shows a direct positive association with water need and the peripheral water needs are more than the core. The significant difference, however, is not as strong as the other variables. The difference may be explained by the large family sizes of residents at the urban margins and slums and the poor hygienic conditions that require enough water to maintain decent sanitation.

\section{[ TABLES 3-5 ]}

The water needs of wives exceed those of their husbands as evidenced by the survey. The mean water needs of husbands, as proportion of the needs of families, are indicated in Table 6 . On the average, a husband needs about one-fifth of the daily water requirements of the family. Given that the average number of children is 3 for both places, this proportion gives the impression that women use water more than their husbands as the interview reveals.

\section{[ TABLE 6 ]}

Water needs met during scarcity by age, marital status and number of children could be depicted by correlation analysis (Appendices B and C). Differences are significant for marital status and by place of residence, but not for age and number of children. What this generally implies is that availability of water during scarcity may depend upon access, but not the quantity needed. The married are able to get greater quantity of their needs than the unmarried. This may be explained by the strong obligation of the wife to satisfy her husband's domestic demands, which involve water. The preparation of meals, washing of the husband's clothes, and maintenance of personal hygiene are more compelling factors for the wife to make every effort to obtain enough water for the home during periods of scarcity. In a typical matrimonial society, age has no effect on water fetching. The difference in hours for fetching water by age is not statistically significant (Table 7).

\section{[ TABLE 7 ]}

\section{Water scarcity, poverty and health}

A relationshipis drawn between water scarcity, poverty and health. The rationale is to find out whether water scarcity affects income, and whether poverty affects health; thus, whether water scarcity affects health. The income of entrepreneurs and traders during regular supply and during scarcity ${ }^{2}$ and their health conditions during regular supply and during scarcity are, respectively,

\footnotetext{
${ }^{1}$ Respondents intimated that it is mostly during the dry season that water scarcity is experienced; and that during the rainy season, they satisfy all their water requirements.

${ }^{2}$ Entrepreneurs whose activities involve the use of water were selected into the sample. Traders reported that they had to go to work very late due to water fetching. Moreover, they reported that business activities declined during the dry season.
} 
Buor, D.

Water needs and women's health in the Kumasi metropolitan area, Ghana.

Health \& Place: 10, 2004, nr. 1, p. 85-103

indicated in Figs. 4 and 5. There is a clear difference between net weekly income during regular supply and net weekly income during scarcity.

There is also a great difference between health status during regular supply, and during scarcity. Table 8 shows the relationship between water quality during scarcity and health. There is a positive relationship between water quality and health. The difference is significant at 0.001 probability $(p \leq 0.001)$ using $\chi^{2}$. As water quality increases, health status also increases. The problem of water underlies most of the health problems in developing countries. Most of the infections are either waterwashed, water-based or water related. The statistics confirm the fact that water scarcity creates poverty and also has an influence on health status.

\section{[ FIGURES 4-5 ] [ TABLE 8 ]}

There are differences in net weekly income and health status during regular supply and scarcity by place of residence (Appendix A). Regarding net weekly income during regular supply and scarcity, it could be concluded from the data that, although there is a general difference in average income between core and periphery, the difference between times of scarcity and regular supply is the same. The periphery, though realises smaller income, is not affected harder by times of scarcity. With regard to health status and water supply however, the health status of the people at the core is less affected than those in the periphery. Differences in the distribution for the two variables are significant using $\chi^{2}$.

Net weekly incomes are lower for the periphery than the core during both regular flow and scarcity. The core enjoys relatively better supply of water during scarcity. Health status is relatively better for residents at the core than at the periphery during both regular and scarce supply of water. By virtue of wealth and social status, residents at the core are better able to access health facilities, and their nutritional status is likely to be better. They also have better access to quality water than those at the periphery, even during scarcity.

Another aspect of the impact of water scarcity on health is the impact of the hours spent fetching water. There is a direct relationship between hours spent fetching water and health status. Hours spent fetching water during scarcity make a greater impact on health than during regular water supply, as depicted by the bar graphs (Figs. 6 and 7, respectively). Hours of water fetching during regular supply have no impact on health. The impact of water fetching on health is, however, strong during water scarcity when long hours have to be spent fetching water. As hours spent fetching water during scarcity declines, health status improves, implying an inverse relationship between water fetching during scarcity and health. There is however no significant difference between hours spent fetching water during scarcity and health by place of residence. The probability value by $\chi^{2}$ is 0.675 , whereas that for hours spent during scarcity is 0.048 .

\section{[ FIGURES 6-7 ]}

\section{Multiple regression analysis}

Multiple regression analysis was made to measure the relative strengths of selected variables on health. Multiple regression is preceded by bivariate correlations (Appendices B and C) to show the associations between the independent variables and health for total sample and place of residence.

The matrix does not show any multicollinearity problems. Water need was not used in the regression analysis, so the high correlation of number of children and age with it did not create a multicollinearity problem. For the variables selected into the regression model, five of them exhibit significant correlations with health during scarcity (at $p=0.01)$ for total sample. These are hours spent on water fetching during scarcity, source of water supply (water quality), proportion supplied during scarcity, education and income. So far, income, water quality and hours spent fetching water show the highest correlation with health during scarcity. There are differences between the core and periphery. For the core, the variables that show significant association with health during scarcity are education, income and hours spent during scarcity, whilst for the periphery they are income and water quality. The main 
difference is water quality that has no effect on the core but has a significant effect on the periphery. The multiple regression (stepwise) factors, which reflect on the bivariate correlations, are indicated in Appendix D.

Based on the stepwise results, four variables that are significant in explaining health for total sample are income, water quality, hours spent fetching water and age. Income has the highest coefficient, so has the greatest effect on health. This is followed by water quality. For the core, two variables have significant effects on health. These are education and hours spent fetching water during water scarcity, whilst the same variables that affect health for the total sample also affect health for the periphery. The five variables, namely income, water quality, hours spent fetching water, age and education that emerged from all three areas were entered as a single regression model (Table 9) to ensure a common basis for comparison.

\section{[ TABLE 9 ]}

The adjusted coefficient of determination (adjusted $R^{2}$ ) is highest for the core than total sample and the periphery. Whereas for total sample the key variables that influence health are income, water quality, hours spent fetching water and age, following an order of importance, those for the core are education, and hours spent fetching water. For the periphery, the significant variables are income, hours spent fetching water, water quality and age.

\section{Quality of water and health problems}

Field data show a relationship between quality of water and predominant diseases of respondents (Table 10). Respondents were asked to indicate their major sources of water supply and their most predominant health problems. Of diseases directly linked with water pollution, diarrhoeal infections, intestinal worms and typhoid are outstanding. For users of stream, which is the most unsafe, diarrhoeal infection, intestinal worms and typhoid constitute $70.4 \%$, as against $8.4 \%$ for treated pipe-borne water. ${ }^{3}$ This confirms the multiple regression results that water quality has a significant impact on health.

\section{[ TABLE 10 ]}

\section{DISCUSSION}

It is evident in the survey that income, water quality and hours spent fetching water during scarcity are the significant factors influencing the health of women in the metropolis during water scarcity. Water scarcity has been found to affect income, as evident in the economic activities of the entrepreneurs and traders. In effect therefore, the water problem directly and indirect affects the health of women in the metropolis. Water quality has a direct effect on the health of women, whilst income, which is directly affected by the water problem, has an effect on health. It could be concluded that the water problem also has an indirect effect on health since it is a causative factor of poverty.

Water fetching, especially during periods of scarcity, has a significant effect on the health of women who bear most of the burdens of the home. Women are culturally obliged to provide the household with water, being consigned to most of the domestic burdens. Even among schoolchildren, girls bear the domestic burden, apart from water fetching, of sweeping, scrubbing, washing of dishes and clothing and preparation of food. The situation may differ by the social status of the couple, in case of the married. Among the educated couple for instance, the woman enjoys some autonomy, participating in family decisions. Husbands with higher education are more likely to support their wives in domestic services.

The quality of water has an effect on the health of women, especially during periods of water scarcity when some families are compelled to use marginal, unsafe water. In the event of acute scarcity, traditional Ghanaian women would like to satisfy the needs of their husbands first. With women

\footnotetext{
${ }^{3}$ Rainwater was removed because of its insignificant relationship with disease.
} 
Buor, D.

Water needs and women's health in the Kumasi metropolitan area, Ghana.

Health \& Place: 10, 2004, nr. 1, p. 85-103

constituting the greater proportion of the metropolitan population, and also requiring enough water to maintain personal hygiene, by virtue of their biological make-up, they are more likely to suffer from the effects of water scarcity.

The survey has also established that differences by age in hours spent fetching water are not statistically significant, even though adult females use more water. The culture of the people requires that the young provide such domestic services, whilst the old provide services that require money. The trend is changing of late. Traditional values seem to be collapsing. Some blame this on increasing modernisation, especially in the urban areas where some young ones are compelled to earn income to take care of their needs. The domestic services required of them are thus not forthcoming.

There are differences by place of residence, regarding the water problem and the factors that influence the health of women in the metropolis. Whereas education and the hours spent fetching water, following an order of importance, have significant effects on health at the core, income, hours spent fetching water, water quality and age have significant effects on health at the periphery. As far as the water problem is concerned, the main risk factor affecting both the core and the periphery is water fetching. The strain of water fetching affects both the core and the periphery during scarcity. A major factor affecting health status for total sample and the periphery is income. The poverty factor is pronounced in the periphery and influences health through poor nutrition, housing and poor access to health facilities, which factors are predominant at the periphery. Whereas education is the main factor influencing health at the core, it has no significant effect in the periphery. The main reason to adduce is that education is a stronger variable factor at the core than the periphery. The educated are more likely to treat unsafe water than the illiterate, and even spend money intended for leisure to buy safe water during scarcity. ${ }^{4}$

The risk factor for health, apart from water fetching in the periphery, is the quality of water, which is a strong determinant of health. Quality of water does not influence health at the core where more than 90 per cent of the respondents use treated pipe water. Water quality is therefore not a variable factor at the core. Residents at the periphery are not provided with as many water-supply facilities as those at the core. Moreover, residents at the periphery, being of lower social and wealth status, are not capable of effectively maintaining the water-supply infrastructure. Some have made illegal connections, which affect supply. Some rely on rainwater, boreholes and wells, which would require treatment before consumption. They thus do not get the minimum quantities during scarcity. This lack of water would seriously affect personal and environmental hygiene, with concomitant health risks. Moreover, they are compelled to use marginal, unsafe water during scarcity for domestic services. Some are compelled to rely on streams, which are the most unsafe source of water supply in the metropolis.

Whereas age influences health status in the periphery, it has no effect on the core. Health status declines as age increases. The aged use more water than the youth, and the stress of water fetching during scarcity could affect health. Moreover, older women are more likely to be married and would need enough water. Besides older women have higher family sizes so would need enough water.

The disease patterns, as related to water quality, confirm the effect of water on health, especially during the lean season of water supply. Diseases like diarrhoeal infections, intestinal worms, viral hepatitis and typhoid constitute 41 per cent of the predominant diseases reported by respondents who use the stream as their main source of water supply. On the other hand, only 8.2 per cent using pipeborne water suffer from such diseases.

Other results on women and health in the metropolis come up for discussion. Men fail to assist their wives in fetching water for the home. Results show that 69.8 per cent of husbands do not support their wives in water fetching. They are not able to reconcile the need of their wives for more water with the cultural factor of woman take- all in domestic services. The cultural hindrance is quite enormous, especially at the periphery where social status is low, and which shows certain characteristics of a rural area.

The study has also shown that the core is able to satisfy their water needs more than the periphery. The reasons for the significance difference by place of residence are not far fetched. The supply of water to the core is greater than to the periphery. This may be explained by political power, ability to

\footnotetext{
${ }^{4}$ Those who have adequate storage facilities to store enough water during adequate supply sell water at high cost during scarcity.
} 
pay, and social status. Government officials and policy makers who have control over distribution patterns during scarcity reside at the core. Second, the wealthy and powerful entrepreneurs who have the ability to pay to maintain supply reside at the core ${ }^{5}$. Third, some major industries that need water to operate are at the core. The demands of such industries, powerful entrepreneurs and politicians who are situated at the core are given priority attention during scarcity when water is rigidly regulated.

Finally, class, as evident in income and education, influences the health of women during scarcity of water. Whereas health is influenced by income for the entire sample, it is influenced by education for the core and income for the periphery. For there to be equity in health, the class system needs to be critically examined. The closing of yawning gaps in educational and wealth status is more likely to close the gap in health status.

Given the great impact that water need has on the development of women, their involvement in water management programmes in the rural and urban areas is needed. Unfortunately, the role of women in decisionmaking in developing countries is rather insignificant. In the Arusha project in Tanzania, the Swedish Agency for Development Cooperation (SIDA, 1993) was discouraged to find that in theory, men and women participate in water and sanitation projects equally at all levels, i.e. planning, implementation, operation and maintenance, and evaluation, but, in fact, women still tend to be implementers and men the decision-makers at village levels. Unfortunately, it was discovered that, when training opportunities for water management are offered to both men and women, women's attendance was poor. In the metropolis, there are no water management committees for the communities. It is the Metropolitan Assembly ${ }^{6}$ that takes responsibility for water management. Unfortunately, women's participation in local and national politics is disappointingly low.

Some hypotheses that guided this study have been vindicated, whilst others have been invalidated. Income, rather than water fetching and water quality, is the main factor influencing health status of women during water scarcity in the metropolis. The hypothesis that the urban periphery suffers more from the health effects of water scarcity, women's poverty being a function of water scarcity during, and women's health being a function of their income have been validated.

An empirical model on water and women's health in the metropolis has emerged (Fig. 8). The model shows the relationship between water-related factors, as well as confounding factors, on women's health. Whereas the relationship between the entire metropolis and the periphery is very strong, that between the core and the metropolis, and the core and periphery are weak.

\section{[ FIGURE 8 ]}

\section{Policy implications}

To address the perennial water shortage and concomitant repercussions on the health, and generally, the development of women, and to ensure gender equity in the burden of accessing water for domestic use, the following policy implications emerge:

(1) There must be aggressive measures to forestall the encroachment on the land at the dam areas. The degraded watersheds must be re-afforestated to ensure regular volume of water and to avoid the excessive evaporation that results in declining volumes and also affects the quality of water.

(2) There must be a programme to restore the regular flow of streams in the metropolis by planting trees at their headwaters and dredging the river valleys. The volumes of such streams could increase and serve as sources of water for some domestic services like scrubbing and cooking.

(3) There must be strong measures to ensure judicious use of treated water. The use of treated water for city horticulture must be stopped. Efforts must be made by metropolitan authorities and water companies to harvest meteoric showers that are abundant during the rainy season in huge aquifers at selected spots in the metropolis for such and other use during scarcity of treated water.

(4) The planning for water resource management does not take the grassroots into consideration. Communities must be involved in the planning for water management. Communities should also be responsible for the management of the standpipes to ensure effective use of water. By doing so they

\footnotetext{
${ }^{5}$ Sometimes scarcity is caused by the cut in supply by the Water Company for non-payment of tariffs. This could happen even during periods of regular supply from the supply source.

${ }^{6}$ The Metropolitan Assembly is the political authority for the management of the metropolis.
} 
shall appreciate the problems associated with water supply. Management committees must involve women who face the greater burden of water supply in the home. The men must also be well informed about the rigours associated with fetching water for the family, in the event of scarcity.

(5) Male dominance at the home, and the overburdening of women in the domestic service could be mitigated if women's education were improved. The only way to ensure greater intimacy, consultation in family decisions and gender equality in the family is education (Lloyd, 1966; Blood, 1972). Education could also result in gainful employment of the woman that increases her power in the home (Nye and Berardo, 1973).

(6) There must be positive measures to control fertility. These include education on family planning; making birth control facilities and family planning clinics easily accessible, especially to the deprived rural population and those at the urban margins; and, ensuring easy access of the girl child to basic education.

(7) There must be a programme to educate women, especially the illiterate, on water purification and storage strategies. The problem of water quality would reduce only when the illiterate masses and the vulnerable are educated on safe water measures.

\section{CONCLUSION}

This survey has attempted to analyse the health effects of water on women in an expanding metropolis in Ghana. It is evident by the survey that women, who bear the burden of water fetching in the home, suffer adverse health effects during water scarcity. Nonetheless, income makes the most significant impact on the health of women in the metropolis during water scarcity, thus, amplifying class as a factor in health status in the metropolis. At the urban core, education is the most significant factor influencing health status during scarcity, whilst at the periphery, it is income, which incidentally is determined by the quantity of water supply. With water scarcity resulting in declining incomes of urban women, the indirect effect of water scarcity on the health of women is established. With a heavy domestic burden of women, the non-assistance of their husbands in water fetching during water scarcity is difficult to contemplate. The need to break down the stranglehold of culture in the area of domestic services by women needs to be addressed, especially, in the area of providing critical facilities like water. Whilst government should ensure sustainable water supply by conserving the ecology around the headwaters of the Owabi and Barekese dams, effective management, involving women, of the daily water supply, must be given an enhanced attention.

\section{ACKNOWLEDGEMENTS}

I am grateful to The Netherlands Foundation for the Advancement of Tropical Research (WOTRO), Den Haag, that funded this research, and to The Netherlands Institute for Health Services Research (NIVEL), Utrecht, that provided some logistic support. I am also grateful to Professor Jouke van der Zee and Professor Peter Groenewegen, both of NIVEL, for their comments and contributions. 
Buor, D.

Water needs and women's health in the Kumasi metropolitan area, Ghana.

Health \& Place: 10, 2004, nr. 1, p. 85-103

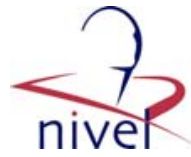

\section{TABLES AND FIGURES}

Table 1

Population of Kumasi metropolis, 1960-2000

\begin{tabular}{lcc}
\hline Census year & Population & Percentage increase \\
\hline $1960^{\mathrm{a}}$ & 201,551 & - \\
$1970^{\mathrm{a}}$ & 293,947 & 45.8 \\
$1984^{\mathrm{a}}$ & 489,586 & 66.6 \\
$2000^{\mathrm{b}}$ & $1,170,270$ & 139.0 \\
\hline
\end{tabular}

Sources: ${ }^{a}$ Based on Ghana Statistical Services (GSS) Service, 1987.

${ }^{\mathrm{b}} \mathrm{GSS}, 2002$.

Table 3

Percentage distribution of daily water needs by age/reproductive status

\begin{tabular}{lllrl}
\hline $\begin{array}{l}\text { Daily needs } \\
\text { (in gallons) }\end{array}$ & \multicolumn{2}{l}{ Age/biological status } & \multicolumn{2}{c}{ Significance } \\
\cline { 2 - 4 } & Less than 14 & $14-49$ & $50+$ & \\
\hline Less than 10 & 84.6 & 16.4 & 0.0 & 0.000 \\
$10-20$ & 15.4 & 31.1 & 14.3 & \\
$21-40$ & 0.0 & 42.1 & 35.7 & \\
$41+$ & 0.0 & 10.4 & 50.0 & \\
\hline
\end{tabular}

Source: Based on Field Data, 2001.

Table 5

Percentage distribution of daily water needs by number of children

\begin{tabular}{lcrrr}
\hline $\begin{array}{l}\text { Daily needs } \\
\text { (in gallons) }\end{array}$ & \multicolumn{2}{l}{ Number of children } & \multicolumn{2}{c}{ Significance } \\
\cline { 2 - 4 } & Less than 3 & $3-5$ & $6+$ & \\
\hline Less than 10 & 3.4 & 0.0 & 0.0 & 0.000 \\
$10-20$ & 29.3 & 0.0 & 0.0 & \\
$21-40$ & 67.2 & 74.1 & 14.3 & \\
$41+$ & 0.0 & 25.9 & 85.7 & \\
\hline
\end{tabular}

Source: Based on Field Data, 2001.

Table 7

Hours spent fetching water by age group

\begin{tabular}{lrrr}
\hline Age group & \multicolumn{3}{l}{ Hours } \\
\cline { 2 - 4 } & \multicolumn{1}{c}{1} & $2-3$ & $4+$ \\
\hline Less than 14 (\%) & 8.3 & 66.7 & 25.0 \\
$14-49(\%)$ & 25.9 & 46.9 & 27.2 \\
$50+(\%)$ & 38.5 & 46.2 & 15.4 \\
\hline
\end{tabular}

Note: Significance by $\chi^{2}$ test: 0.434 .

Source: Based on Field Data, 2001.

Water quality and health during scarcity

\begin{tabular}{lrrrrr}
\hline Health status $^{\mathrm{a}}$ & \multicolumn{6}{l}{ Water quality (\%) } \\
\cline { 2 - 6 } & Stream & $\begin{array}{l}\text { Hand-dug } \\
\text { well }\end{array}$ & Rain & Borehole & Pipe \\
\hline Once in 2 weeks & 59.5 & 34.3 & 100.0 & 20.0 & 11.0 \\
Once a month & 27.0 & 37.1 & - & 33.3 & 24.6 \\
Once in 3 months & 10.8 & 22.9 & - & 33.3 & 44.9 \\
Rarely & 2.7 & 5.7 & - & 13.3 & 19.5 \\
\hline
\end{tabular}

Source: Based on Field Data, 2001.

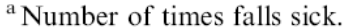

\begin{tabular}{llcl}
\hline $\begin{array}{l}\text { Daily needs } \\
\text { (in gallons) }\end{array}$ & \multicolumn{2}{c}{ Marital status } & Significance \\
\cline { 2 - 3 } & Unmarried & Married & \\
\hline Less than 10 & 36.3 & 0.0 & 0.000 \\
$10-20$ & 46.0 & 9.3 & \\
$21-40$ & 15.0 & 67.0 & \\
$41+$ & 2.7 & 23.7 & \\
\hline
\end{tabular}

Table 6

Husbands' mean daily water needs (gallons) as percentage of mean needs of families by place of residence

\begin{tabular}{llll}
\hline Residence & Families' needs & Husbands' needs & $\%$ \\
\hline Centre & 21.88 & 5.05 & 23.1 \\
Periphery & 25.27 & 4.57 & 18.1 \\
Total sample & 23.81 & 4.76 & 19.9
\end{tabular}

Source: Based on Field Data, 2001. 
Buor, D.

Water needs and women's health in the Kumasi metropolitan area, Ghana.

Health \& Place: 10, 2004, nr. 1, p. 85-103

Table 9

Multiple regression coefficients for independent variables

\begin{tabular}{|c|c|c|c|c|c|c|}
\hline \multirow[t]{2}{*}{ Variables } & \multicolumn{2}{|c|}{ Total sample } & \multicolumn{2}{|l|}{ Core } & \multicolumn{2}{|l|}{ Periphery } \\
\hline & Beta coef. & Signif. & Beta coef. & Signif. & Beta coef. & Signif. \\
\hline Income & 0.409 & 0.000 & 0.251 & 0.034 & 0.453 & 0.000 \\
\hline Water quality & 0.307 & 0.000 & 0.047 & 0.646 & 0.288 & 0.003 \\
\hline Hours spent & -0.255 & 0.000 & -0.261 & 0.011 & -0.293 & 0.003 \\
\hline Age & -0.079 & 0.240 & 0.085 & 0.412 & -0.206 & 0.032 \\
\hline Education & 0.085 & 0.258 & 0.487 & 0.000 & -0.183 & 0.055 \\
\hline Adjusted $R^{2}$ & \multicolumn{2}{|c|}{0.417} & \multicolumn{2}{|c|}{0.496} & \multicolumn{2}{|c|}{0.341} \\
\hline
\end{tabular}

Source: Based on Field Data, 2001.

Table 10

Quality of water and disease

\begin{tabular}{|c|c|c|c|c|}
\hline Disease & Stream & $\begin{array}{l}\text { Hand-dug } \\
\text { well }\end{array}$ & Borehole & Pipe \\
\hline Malaria & 9.8 & 45.7 & 43.8 & 33.9 \\
\hline Rheumatism & 0.0 & 2.9 & 6.3 & 5.9 \\
\hline Gastrointestinal & 0.0 & 0.0 & 0.0 & 9.3 \\
\hline Skin infection & 12.2 & 5.7 & 18.8 & 14.4 \\
\hline Diarrhoeal infection & 34.1 & 20.0 & 0.0 & 4.2 \\
\hline Respiratory tract infect. & 0.0 & 0.0 & 6.3 & 3.4 \\
\hline Eye infections & 2.4 & 2.9 & 6.3 & 11.9 \\
\hline Boils & 0.0 & 0.0 & 0.0 & 1.7 \\
\hline Worms & 17.1 & 8.6 & 6.3 & 2.5 \\
\hline Hypertension & 0.0 & 0.0 & 0.0 & 2.5 \\
\hline Gynaecological inf. & 2.4 & 2.9 & 0.0 & 0.8 \\
\hline Typhoid & 19.5 & 11.4 & 0.0 & 2.5 \\
\hline Migraine & 2.4 & 0.0 & 6.3 & 6.8 \\
\hline Diabetes & 0.0 & 0.0 & 6.3 & 0.0 \\
\hline Total & 100.0 & 100.0 & 100.0 & 100.0 \\
\hline
\end{tabular}

Source: Based On Field Data, 2001.

\section{Appendix A}

Distribution of study variables and non-response (see Table 11)

\begin{tabular}{|c|c|c|c|c|}
\hline Variable & $\begin{array}{l}\text { Total sample } \\
n=210\end{array}$ & $\begin{array}{l}\text { Core } \\
n=90\end{array}$ & $\begin{array}{l}\text { Periphery } \\
n=120\end{array}$ & $\begin{array}{l}\text { SIG. } \\
\text { based }\end{array}$ \\
\hline \multicolumn{5}{|l|}{ Age } \\
\hline $0-13$ & 6.2 & 7.7 & 5.0 & 0.434 \\
\hline $14-49$ & 87.1 & 85.7 & 88.2 & \\
\hline $50+$ & 6.7 & 6.6 & 6.7 & \\
\hline Mean (years) & 27.7 & 27.5 & 27.9 & \\
\hline \multicolumn{5}{|c|}{ Marital status (\%) } \\
\hline Married & 53.8 & 58.9 & 50.0 & 0.127 \\
\hline Unmarried & 46.2 & 41.1 & 50.0 & \\
\hline \multicolumn{5}{|c|}{ Employment status (\%) } \\
\hline Unemployed & 48.5 & 48.3 & 48.7 & 0.532 \\
\hline Employed & 51.5 & 51.7 & 51.3 & \\
\hline Missing & 2.9 & 3.3 & 2.5 & \\
\hline
\end{tabular}


Buor, D.

Water needs and women's health in the Kumasi metropolitan area, Ghana.

Health \& Place: 10, 2004, nr. 1, p. 85-103

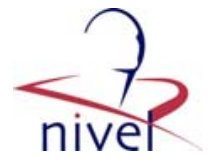

Table 11 (continued)

\begin{tabular}{|c|c|c|c|c|}
\hline Variable & $\begin{array}{l}\text { Total sample } \\
n=210\end{array}$ & $\begin{array}{l}\text { Core } \\
n=90\end{array}$ & $\begin{array}{l}\text { Periphery } \\
n=120\end{array}$ & $\begin{array}{l}\text { SIG. } 1 \\
\text { based }\end{array}$ \\
\hline \multicolumn{5}{|l|}{ Educational status (\%) } \\
\hline Never-been-to-school & 15.2 & 17.8 & 13.3 & 0.000 \\
\hline Basic education & 51.4 & 32.2 & 65.8 & \\
\hline Secondary education & 23.3 & 26.7 & 20.8 & \\
\hline Tertiary education & 10.0 & 23.3 & 0.0 & \\
\hline \multicolumn{5}{|l|}{ Education of husband $(\%)$} \\
\hline Never-been-to-school & 0.0 & 0.0 & 0.0 & 0.071 \\
\hline Basic education & 9.3 & 14.3 & 6.1 & \\
\hline Secondary education & 58.3 & 45.2 & 66.7 & \\
\hline Tertiary education & 32.4 & 40.5 & 27.3 & \\
\hline Missing & 48.6 & 53.2 & 45.0 & \\
\hline \multicolumn{5}{|l|}{ Monthly income (c) } \\
\hline Less than 100,000 & 1.5 & 1.8 & 1.3 & 0.248 \\
\hline $100,000-200,000$ & 14.7 & 7.1 & 20.0 & \\
\hline $201,000-400,000$ & 33.8 & 37.5 & 31.3 & \\
\hline $401,000-600,000$ & 31.6 & 30.4 & 32.5 & \\
\hline $601,000+$ & 18.4 & 23.2 & 15.0 & \\
\hline Mean & 500220.59 & 592678.57 & 435500.00 & \\
\hline SD & 379807.88 & 451853.75 & 306692.85 & \\
\hline \multicolumn{5}{|l|}{ Number of children $(\%)$} \\
\hline Less than 3 & 46.0 & 47.9 & 44.9 & 0.942 \\
\hline $3-5$ & 42.9 & 41.7 & 43.6 & \\
\hline $6+$ & 11 & 10.4 & 11.5 & \\
\hline Mean & 3.13 & 3.23 & 3.08 & \\
\hline \multicolumn{5}{|c|}{ Source of water supply $(\%)$} \\
\hline Stream & 18.8 & 0.0 & 32.5 & 0.000 \\
\hline Hand-dug well & 16.8 & 4.5 & 25.8 & \\
\hline Rain & 0.5 & 0.0 & 0.8 & \\
\hline Borehole & 7.2 & 3.4 & 10.0 & \\
\hline Pipe & 56.7 & 92.0 & 30.8 & \\
\hline Missing & 1.0 & 2.2 & 0.0 & \\
\hline \multicolumn{5}{|c|}{ Hours spent fetching water during regular flow $(\%)$} \\
\hline Less than $1 \mathrm{~h}$ & 61.0 & 82.2 & 45.0 & 0.000 \\
\hline $1-2 \mathrm{~h}$ & 37.6 & 17.8 & 52.5 & \\
\hline $3+h$ & 1.4 & 0.0 & 2.5 & \\
\hline \multicolumn{5}{|c|}{ Hours spent fetching water during scarcity ( $\%)$} \\
\hline Less than $2 \mathrm{~h}$ & 23.3 & 30.0 & 18.3 & 0.138 \\
\hline $2-3 \mathrm{~h}$ & 51.9 & 46.7 & 55.8 & \\
\hline $4+$ & 24.8 & 23.3 & 25.8 & \\
\hline \multicolumn{5}{|c|}{ Weekly profit during regular supply (c) (\%) } \\
\hline Less than 50,000 & 38.1 & 20.0 & 51.7 & 0.004 \\
\hline $50,000-100,000$ & 38.1 & 44.4 & 33.3 & \\
\hline $101,000-200,000$ & 18.1 & 24.4 & 13.3 & \\
\hline $201,000+$ & 5.7 & 11.1 & 1.7 & \\
\hline Missing & 50.0 & 50.0 & 50.0 & \\
\hline
\end{tabular}


Buor, D.

Water needs and women's health in the Kumasi metropolitan area, Ghana.

Health \& Place: 10, 2004, nr. 1, p. 85-103

Table 11 (continued)

\begin{tabular}{|c|c|c|c|c|}
\hline Variable & $\begin{array}{l}\text { Total sample } \\
n=210\end{array}$ & $\begin{array}{l}\text { Core } \\
n=90\end{array}$ & $\begin{array}{l}\text { Periphery } \\
n=120\end{array}$ & $\begin{array}{l}\text { SIG. ( } p \text { value) } \\
\text { based on } \chi^{2} \text { test }\end{array}$ \\
\hline \multicolumn{5}{|c|}{ Weekly profit during water scarcity (d) $(\%)$} \\
\hline Less than 50,000 & 57.1 & 40.0 & 70.0 & 0.004 \\
\hline $50,000-100,000$ & 29.5 & 35.6 & 25.0 & \\
\hline $101,000-200,000$ & 9.5 & 15.6 & 5.0 & \\
\hline $201,000+$ & 3.8 & 8.9 & 0.0 & \\
\hline Missing & 50.0 & 50.0 & 50.0 & \\
\hline \multicolumn{5}{|c|}{ General health status (\%) (Frequency of sickness) } \\
\hline Once in 2 weeks & 4.8 & 0.0 & 8.3 & 0.021 \\
\hline Once a month & 13.4 & 11.2 & 15.0 & \\
\hline Once in 3 months & 32.1 & 31.5 & 32.5 & \\
\hline Rarely & 49.8 & 57.3 & 44.2 & \\
\hline Missing & 0.5 & 1.1 & 0.0 & \\
\hline \multicolumn{5}{|c|}{ Health status during scarcity (Frequency of sickness) } \\
\hline Once in 2 weeks & 24.6 & 6.7 & 38.1 & 0.000 \\
\hline Once a month & 28.0 & 24.7 & 30.5 & \\
\hline Once in 3 months & 33.8 & 48.3 & 22.9 & \\
\hline Rarely & 13.5 & 20.2 & 8.5 & \\
\hline Missing & 1.4 & 1.1 & 1.7 & \\
\hline \multicolumn{5}{|c|}{ Daily water needs (gallons) } \\
\hline Less than 10 & 19.5 & 31.1 & 10.8 & 0.004 \\
\hline $10-20$ & 29.0 & 24.4 & 32.5 & \\
\hline $21-40$ & 39.0 & 34.4 & 42.5 & \\
\hline $41+$ & 12.4 & 10.0 & 14.2 & \\
\hline \multicolumn{5}{|c|}{ Proportion of daily water needs met during scarcity } \\
\hline Less than $25 \%$ & 13.3 & 4.4 & 20.0 & 0.003 \\
\hline $25-50 \%$ & 58.1 & 48.9 & 65.0 & \\
\hline $51-75 \%$ & 18.6 & 30.0 & 10.0 & \\
\hline $76 \%+$ & 10.0 & 16.7 & 5.0 & \\
\hline \multicolumn{5}{|c|}{ Does your husband assist you in water fetching? } \\
\hline Yes & 30.2 & 38.1 & 25.0 & 0.112 \\
\hline No & 69.8 & 61.9 & 75.0 & \\
\hline
\end{tabular}

Note: $d 7000=\$ 1$ at the time of collecting the data in 2001 .

Source: Based on Field Data, 2001. 
Buor, D.

Water needs and women's health in the Kumasi metropolitan area, Ghana.

Health \& Place: 10, 2004, nr. 1, p. 85-103

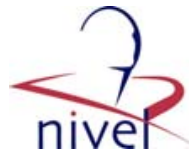

\section{Appendix B}

Correlation matrix for study variables (see Table 12)

Table 12

\begin{tabular}{|c|c|c|c|c|c|c|c|}
\hline \multirow[t]{2}{*}{ Variables } & \multicolumn{7}{|c|}{ Variables/correlations } \\
\hline & Health scar. & General hea. & Age & Education & Marital status & Employment & No. children \\
\hline Health scarc. & 1.000 & & & & & & \\
\hline General hea. & $0.583^{* *}$ & 1.000 & & & & & \\
\hline Age & -0.048 & -0.066 & 1.000 & & & & \\
\hline Education & $0.335^{* * *}$ & $0.259^{* *}$ & $-0.214^{* *}$ & 1.000 & & & \\
\hline Marital status & -0.001 & 0.022 & $0.462^{* *}$ & -0.060 & 1.000 & & \\
\hline Employment & -0.013 & -0.058 & $0.616^{* *}$ & -0.069 & $0.542^{* *}$ & 1.000 & \\
\hline No. children & -0.025 & -0.013 & $0.599^{* *}$ & -0.053 & 0.157 & 0.094 & 1.000 \\
\hline Income & $0.518^{* * *}$ & $0.291^{* *}$ & 0.027 & $0.391^{* * *}$ & $0.234^{* *}$ & 0.093 & 0.142 \\
\hline Water Need & -0.058 & -0.065 & $0.728^{* *}$ & $-0.176^{*}$ & $0.625^{* *}$ & $0.519^{* * *}$ & $0.934^{* *}$ \\
\hline Prop. supp. & $0.195^{* *}$ & 0.097 & -0.062 & $0.222^{* *}$ & -0.015 & -0.082 & -0.031 \\
\hline Water quali. & $0.461^{* *}$ & 0.125 & 0.075 & 0.106 & -0.025 & 0.059 & 0.028 \\
\hline Hours reg. & -0.099 & 0.011 & 0.102 & $-0.178^{* *}$ & $0.181^{* *}$ & 0.068 & $0.192^{*}$ \\
\hline Hours scar. & $-0.211^{* *}$ & $-0.179^{* *}$ & -0.037 & -0.074 & 0.053 & -0.092 & 0.042 \\
\hline & Income & Water need & Prop supp. & Water quali. & Hours reg. & Hours scar. & \\
\hline \\
\hline \multicolumn{8}{|l|}{$\begin{array}{l}\text { General hea. } \\
\text { Age }\end{array}$} \\
\hline \multirow{2}{*}{\multicolumn{8}{|c|}{$\begin{array}{l}\text { Age } \\
\text { Education }\end{array}$}} \\
\hline & & & & & & & \\
\hline \multicolumn{8}{|l|}{ Marital status } \\
\hline \multicolumn{8}{|l|}{ Employment } \\
\hline \multicolumn{8}{|l|}{ No. children } \\
\hline Income & 1.000 & & & & & & \\
\hline Water need & 0.114 & 1.000 & & & & & \\
\hline Prop. supp. & $0.186^{*}$ & -0.048 & 1.000 & & & & \\
\hline Water quali. & $0.177^{*}$ & 0.027 & $0.248^{* *}$ & 1.000 & & & \\
\hline Hours reg. & -0.054 & $0.288^{* *}$ & $-0.206^{* *}$ & $-0.263^{* *}$ & 1.000 & & \\
\hline Hours. scar. & -0.089 & 0.037 & -0.098 & 0.011 & $0.388^{* * *}$ & 1.000 & \\
\hline
\end{tabular}

Source: Based on Field Data, 2001.

* Correlation is significant at the 0.05 level (two-tailed).

** Correlation is significant at the 0.01 level (two-tailed).

\section{Appendix C}

Correlation matrix for study variables for the core and periphery (see Table 13)

Table 13

\begin{tabular}{lccccccc}
\hline Variables & \multicolumn{7}{l}{ Variables/correlations } \\
\cline { 2 - 7 } & Health scar. & General hea. & Age & Education & Marital status & Employment & No. children \\
\hline Health scarc. & $\mathbf{1 . 0 0 0}$ & $0.618^{* *}$ & -0.032 & $0.546^{* *}$ & 0.017 & -0.046 & -0.111 \\
General hea. & $0.545^{* *}$ & $\mathbf{1 . 0 0 0}$ & -0.010 & $0.400^{* *}$ & 0.026 & -0.039 & 0.002 \\
Age & -0.042 & -0.092 & $\mathbf{1 . 0 0 0}$ & -0.140 & $0.447^{* *}$ & $0.580^{* *}$ & $0.606^{* *}$ \\
Education & -0.047 & 0.089 & $-0.347^{* *}$ & $\mathbf{1 . 0 0 0}$ & -0.101 & -0.122 & -0.186 \\
Marital status & 0.017 & 0.026 & $0.447^{* *}$ & -0.101 & $\mathbf{1 . 0 0 0}$ & $0.504^{* *}$ & 0.152 \\
Employment & -0.046 & -0.039 & $0.580^{* *}$ & -0.122 & $0.504^{* *}$ & $\mathbf{1 . 0 0 0}$ & 0.021 \\
No. children & -0.111 & 0.002 & $0.606^{* *}$ & -0.186 & 0.152 & 0.021 & $\mathbf{1 . 0 0 0}$ \\
Income & $0.464^{* *}$ & $0.284^{*}$ & 0.066 & 0.010 & $0.276^{* *}$ & 0.061 & 0.178 \\
Water need & -0.010 & -0.020 & $0.734^{* *}$ & $-0.272^{* *}$ & $0.633^{* *}$ & $0.466^{* *}$ & $0.942^{* *}$ \\
Prop. supp. & 0.021 & 0.026 & -0.123 & 0.136 & -0.076 & $-0.258^{* *}$ & -0.024 \\
Water quali. & $0.394^{* *}$ & 0.010 & 0.103 & -0.079 & 0.025 & 0.058 & 0.004
\end{tabular}


Buor, D.

Water needs and women's health in the Kumasi metropolitan area, Ghana.

Health \& Place: 10, 2004, nr. 1, p. 85-103

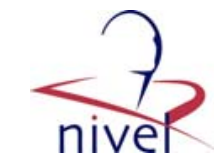

Table 13 (continued)

\begin{tabular}{|c|c|c|c|c|c|c|c|}
\hline \multirow[t]{2}{*}{ Variables } & \multicolumn{7}{|c|}{ Variables/correlations } \\
\hline & Health scar. & General hea. & Age & Education & Marital status & Employment & No. children \\
\hline Hours reg. & 0.064 & 0.089 & 0.132 & -0.152 & 0.160 & 0.090 & $0.289^{*}$ \\
\hline Hours scar. & -0.174 & $-0.239^{* *}$ & 0.054 & -0.129 & 0.098 & 0.059 & 0.161 \\
\hline & Income & Water need & Prop. supp. & Water quali. & Hours reg. & Hours scar. & \\
\hline Health scarc. & $0.543^{* *}$ & -0.018 & 0.139 & 0.009 & -0.001 & $-0.236^{*}$ & \\
\hline General hea. & $0.274^{*}$ & -0.095 & 0.048 & 0.025 & 0.076 & -0.039 & \\
\hline Age & -0.003 & $0.726^{* *}$ & 0.015 & 0.170 & 0.047 & -0.158 & \\
\hline Education & $0.525^{* *}$ & -0.077 & 0.151 & -0.132 & -0.030 & 0.000 & \\
\hline Marital status & $0.272^{*}$ & $0.607^{* *}$ & 0.133 & 0.047 & $0.222^{*}$ & -0.023 & \\
\hline Employment & 0.130 & $0.598 * *$ & 0.128 & 0.136 & 0.047 & $-0.295^{* *}$ & \\
\hline No. children & 0.074 & $0.928 * *$ & -0.078 & 0.123 & 0.021 & -0.145 & \\
\hline Income & 1.000 & 0.036 & 0.206 & 0.039 & -0.115 & -0.110 & \\
\hline Water need & $0.257^{*}$ & 1.000 & 0.064 & 0.085 & 0.172 & -0.180 & \\
\hline Prop. supp. & 0.061 & -0.076 & 1.000 & $0.219^{*}$ & -0.125 & 0.025 & \\
\hline Water quali. & 0.100 & 0.128 & 0.015 & 1.000 & $-0.244^{*}$ & -0.043 & \\
\hline Hours reg. & 0.109 & $0.327^{* * *}$ & -0.103 & -0.056 & 1.000 & $0.287^{* * *}$ & \\
\hline Hours scar. & 0.007 & $0.184^{*}$ & -0.155 & 0.118 & $0.455^{* *}$ & 1.000 & \\
\hline
\end{tabular}

Source: Based on Field Data, 2001.

Note: The values above the diagonal (1.000) are for the core, and those below, the periphery.

* Correlation is significant at the 0.05 level (two-tailed).

** Correlation is significant at the 0.01 level (two-tailed).

\section{Appendix D}

Regression coefficients of selected variables on health for: (a) total sample, (b) core and (c) periphery (see Table 14)

Table 14

\begin{tabular}{|c|c|c|c|}
\hline $\begin{array}{l}\text { (Model) } \\
\text { independent } \\
\text { variables }\end{array}$ & $\begin{array}{l}\text { Beta } \\
\text { coefficient }\end{array}$ & $P$ value & Adjusted $R^{2}$ \\
\hline
\end{tabular}

\begin{tabular}{lrrr}
\hline $\begin{array}{lrl}\text { (a) For total sample } \\
\text { 1. Income }\end{array}$ & 0.508 & 0.000 & 0.252 \\
& & & \\
2. Income & 0.406 & 0.000 & 0.350 \\
Water quality & 0.325 & 0.000 & \\
& & & \\
3. Income & 0.435 & 0.000 & 0.401 \\
Water quality & 0.336 & 0.000 & \\
Hours spent & -0.235 & 0.000 & \\
fetching water & & & \\
& & & \\
4. Income & 0.443 & 0.000 & 0.417 \\
Water quality & 0.351 & 0.000 & \\
Hours spent & -0.235 & 0.001 & \\
fetching water & & & \\
Age & -0.145 & 0.041 &
\end{tabular}

Table 14 (continued)

\begin{tabular}{llll}
\hline $\begin{array}{l}\text { Model) } \\
\text { independent } \\
\text { variables }\end{array}$ & $\begin{array}{l}\text { Beta } \\
\text { coefficient }\end{array}$ & $P$ value & Adjusted $R^{2}$ \\
\end{tabular}

\begin{tabular}{lrrr}
\hline (b) For the core & & & \\
1. Education & 0.583 & 0.000 & 0.324 \\
& & & \\
2. Education & 0.571 & 0.000 & 0.395 \\
$\begin{array}{l}\text { Hours spent } \\
\text { fetching water }\end{array}$ & -0.290 & 0.019 & \\
& & & \\
(c) For the periphery & & & \\
1. Income & 0.469 & 0.000 & 0.210 \\
& & & \\
2. Income & 0.447 & 0.000 & 0.265 \\
Water quality & 0.255 & 0.012 & \\
& & & \\
3. Income & 0.442 & 0.000 & 0.307 \\
Water quality & 0.305 & 0.003 & \\
Hours spent & -0.229 & 0.022 & \\
fetching water & & & \\
& & & \\
4. Income & 0.459 & 0.000 & 0.354 \\
Water quality & 0.322 & 0.001 & \\
Hours spent & -0.240 & 0.013 & \\
fetching water & & & \\
Age & -0.232 & 0.015 & \\
\hline
\end{tabular}

Dependent variable: health status during scarcity. 
Buor, D.

Water needs and women's health in the Kumasi metropolitan area, Ghana.

Health \& Place: 10, 2004, nr. 1, p. 85-103

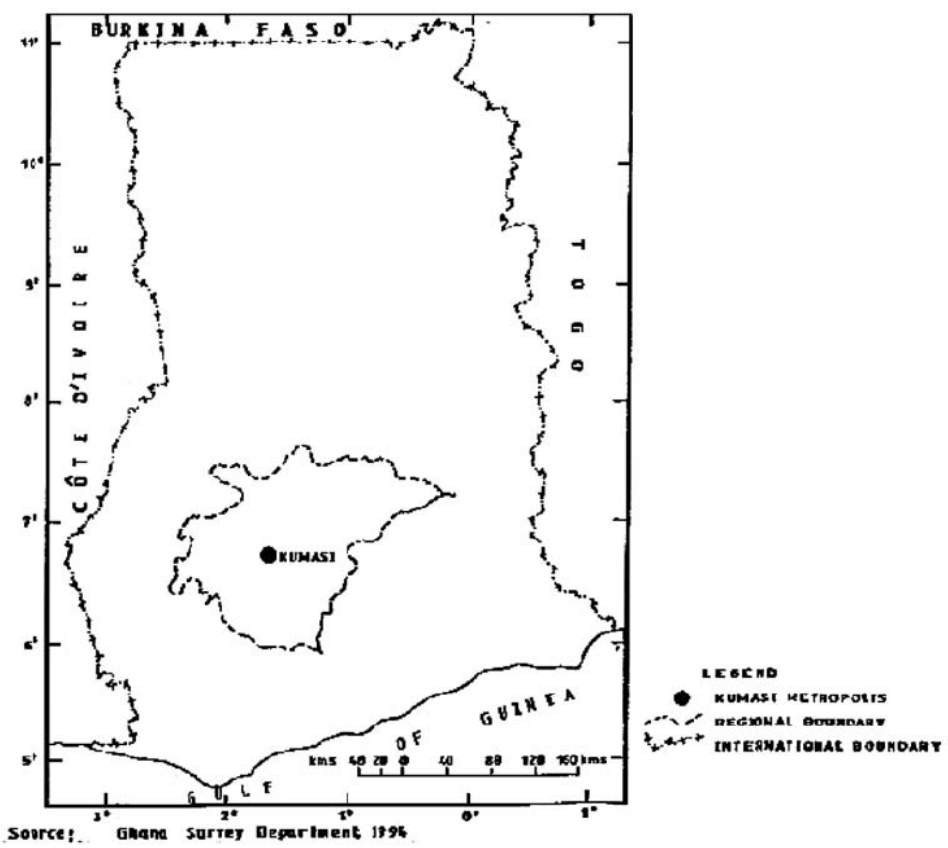

Fig. 1. Kumasi metropolis in national context.

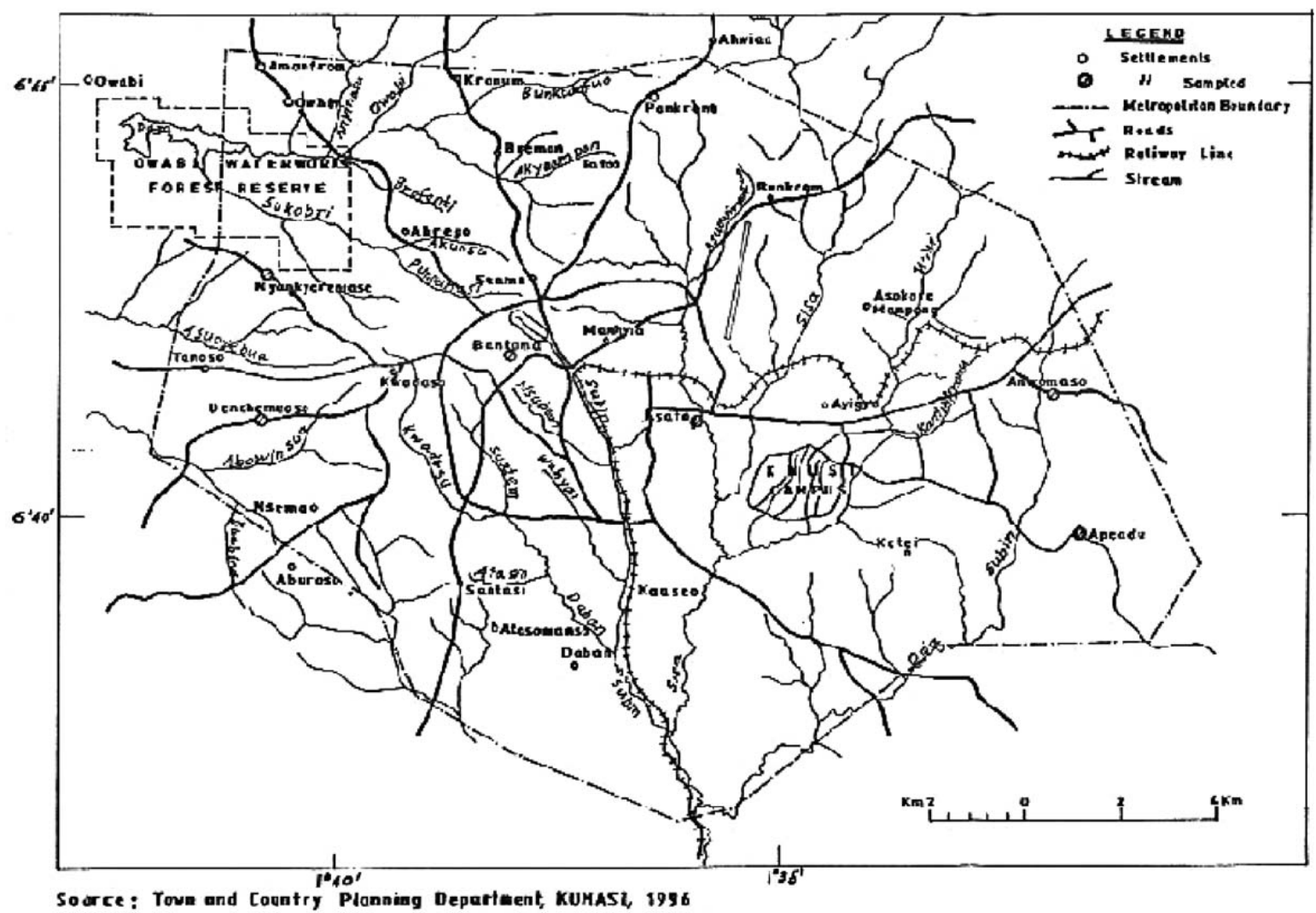

Fig. 2. Kumasi metropolis showing sampled settlements and drainage features. 
Buor, D.

Water needs and women's health in the Kumasi metropolitan area, Ghana.

Health \& Place: 10, 2004, nr. 1, p. 85-103
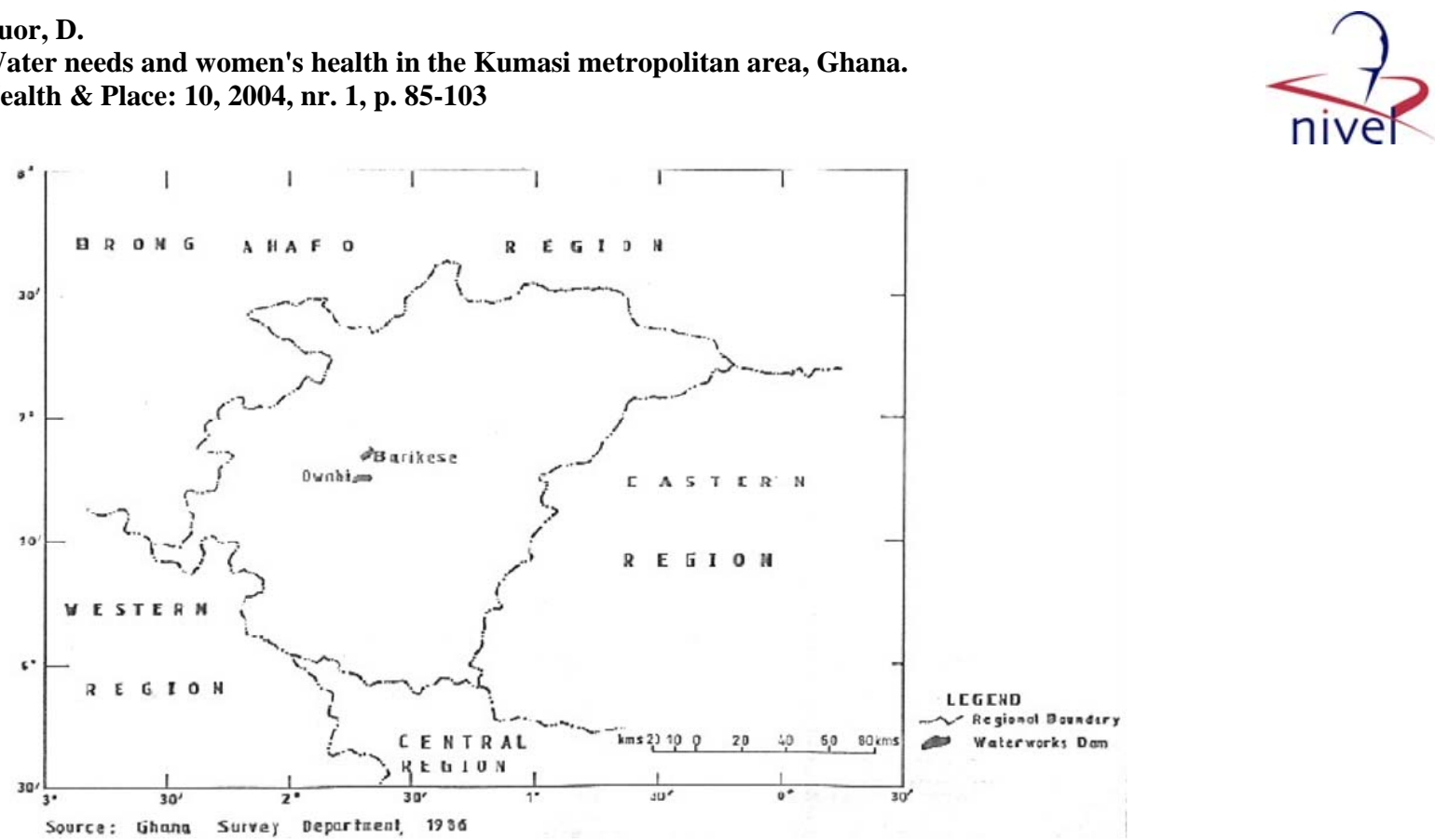

Fig. 3. Ashanti region showing Barekese and Owabi waterworks.
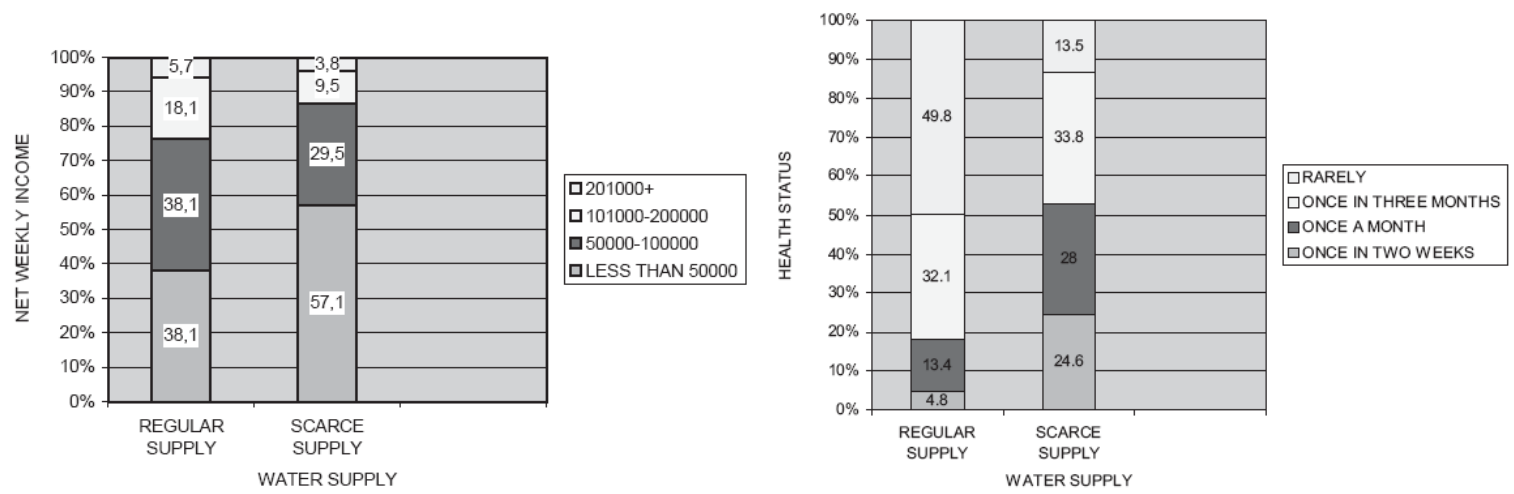

Fig. 4. Percentage distribution of net weekly income during Fig. 5. Percentage distribution of health status during regular regular water supply and during scarcity by total sample. Note: water supply and during scarcity by total sample. Note: Health Income (legend) is in Ghana Cedis (c). Source: Based on Field status (legend) is defined by the number of times a person falls Data, 2001 . sick within a period. Source: Based on Field Data, 2001.
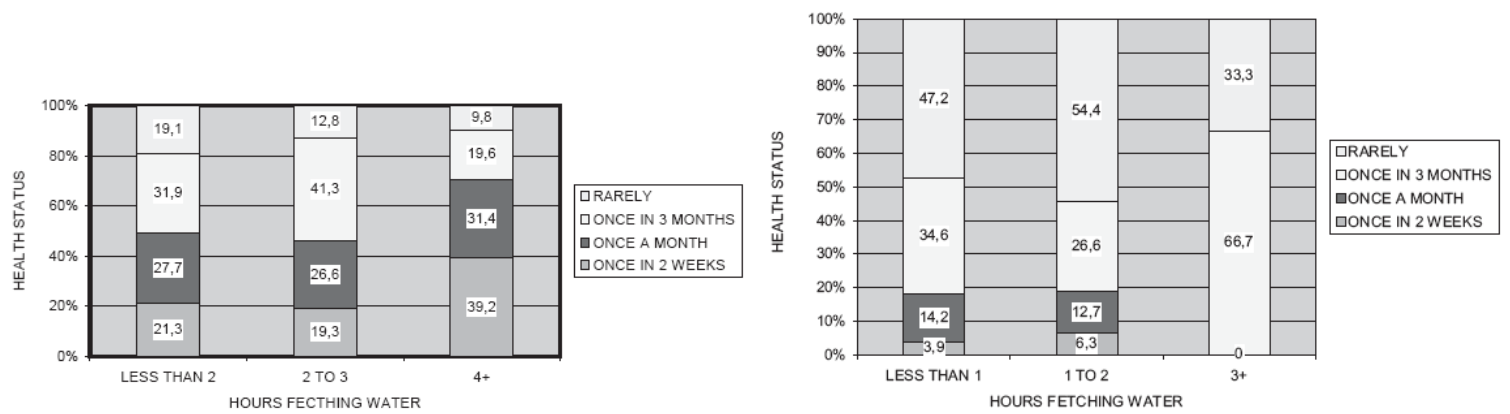

Fig. 6. Percentage distribution of hours for fetching water Fig. 7. Percentage distribution of hours for fetching water during water scarcity and health status. Source: Based on Field during regular supply and health status. Source: Based on Field Data, 2001.

Data, 2001. 
Buor, D.

Water needs and women's health in the Kumasi metropolitan area, Ghana.

Health \& Place: 10, 2004, nr. 1, p. 85-103

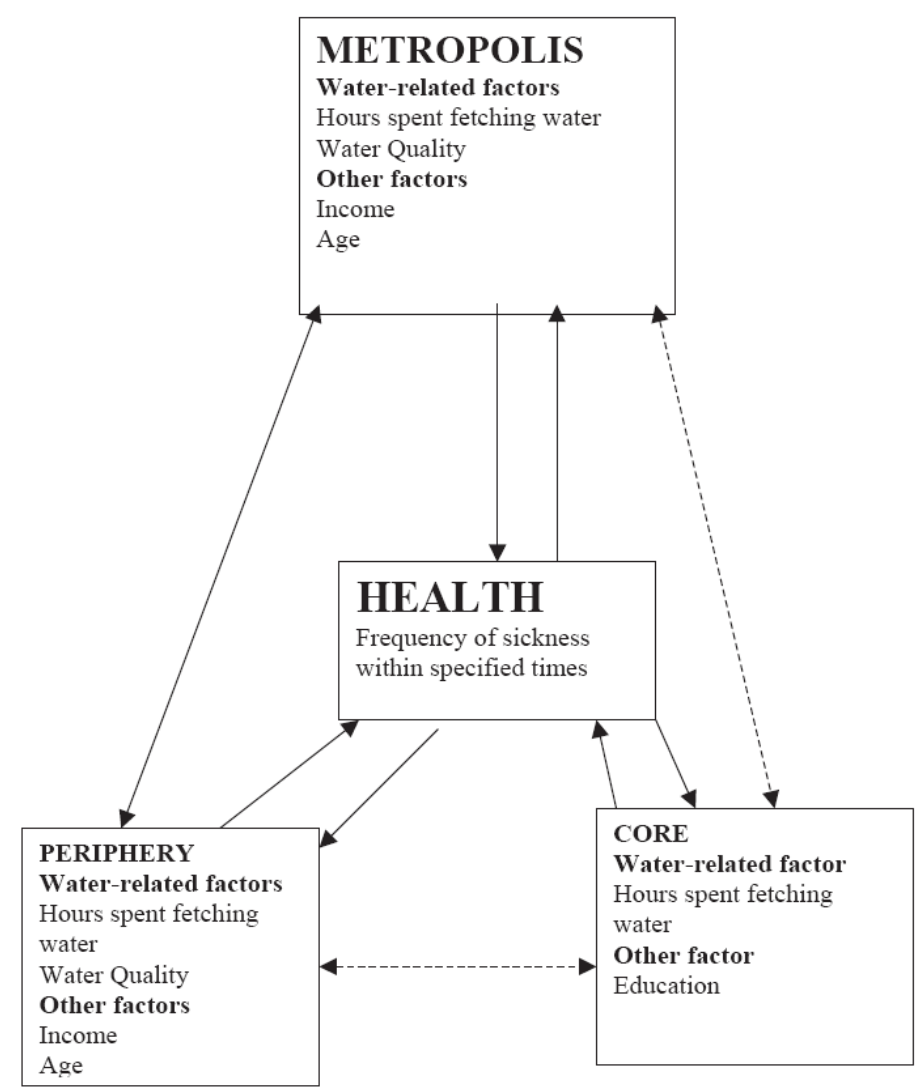

Fig. 8. A conceptual model on water needs and women's health. Source: Based on Empirical Results, 2002.

\section{REFERENCES}

1. Anderson, D.W., Andersen, R.M., 1972. Patterns of use of health services. In: Freeman, H., Freeman, S., Reeder, L. (Eds.), Handbook of Medical Sociology, 2nd Edition Prentice-Hall, Englewood Cliffs, $\mathrm{NJ}$.

2. Benneh, G., 1992. Environmental Consequences of Different Patterns of Urbanization. Presented at the United Nations Expert Group Meeting on Population, Environment and Development. Population Division of the Department of International Economic and Social affairs, UN Secretariat, New York.

3. Blood, Jr. R.O., 1972. The Family. The Free Press, New York, p. 27.

4. Chandni, J., 2000. Keynote Address at the Second World Water Forum. UNIFEM, UN, The Hague.

5. Clarke, R., 1991. Water: The International Crisis. MIT Press, Cambridge, MA, p. xii.

6. Cleary, P.D., Mechanic, J.R., Greenley, J.R., 1982. Sex differences in medical care utilisation: an empirical investigation. Journal of Health and Social Behaviour 23, 106-119.

7. Cleaver, M.K., 1991. The population, agriculture and environment nexus in Sub-Saharan Africa. World Bank Working Paper, Africa Region, Washington, DC.

8. Daily Graphic, 2001. Graphic Communications Ltd. Accra, Ghana, 13 March. Graphic Communications Group Ltd.

9. Davidson, J., Myers, D., Chakraborty, M., 1992. No Time to Waste: Poverty and The Global Environment. Oxfam, Oxford.

10. Feachem, R., McGarry, M., Mara, D. (Eds.), 1986a. Water, Wastes and Health in Hot Climates. Wiley and Sons, New York, p. 82.

11. Feachem, R., McGarry, M., Mara, D. (Eds.), 1986b. Water, Wastes and Health in Hot Climates. Wiley and Sons, New York, p. 81.

12. Ghana Statistical Service, GSS, 1987. 1984 Population Census of Ghana. Accra, p. 37.

13. Ghana Statistical Service, GSS, and Micro International (MI) 1999. 1998 Ghana Demographic and Health Surveys. Accra, p. 27.

14. Ghana Statistical Service, GSS, 2002. 2000 Population and Housing Census, Special Report on 20 Largest Localities. Accra, p. 1. 
Buor, D.

Water needs and women's health in the Kumasi metropolitan area, Ghana.

Health \& Place: 10, 2004, nr. 1, p. 85-103

15. Gleick, P., 2000. Amount of Water per Capita in year 2000 on Global Basis. Global Environmental Program of the Pacific Institute, Oakland, CA.

16. Holly, M., Kristine, W., Barbara, G., Heidi, H., 2001. The influence of income, education, and work status on women's well being. Women's Health Issues 11 (3), 160-172.

17. IRC, 1995a. Gender in Community Water Supply, Sanitation and Water Resource Protection: A Guide to Methods and Techniques. The Hague, The Netherlands, International Rescue Corps (IRC), p. 26.

18. IRC, 1995b. Gender in Community Water Supply, Sanitation and Water Resource Protection: A Guide to Methods and Techniques. The Hague, The Netherlands, International Rescue Corps (IRC), p. 27.

19. Kohn, R., White, K.L. (Eds.), 1978. Health Care: An International Study. Oxford University Press, Oxford.

20. Van der Velden, K., Van Ginneken, J. (Eds.), 1995. Health Matters, Public Health in NorthSouth Perspective. Houten: Bohn Stafleu van Loghum/Amsterdam, Royal Tropical Institute, pp. 129-141.

21. Lean, G., Hinrichsen, D., 1994. Atlas of the Environment. Harper Perennial, New York.

22. Lloyd, B.B., 1966. Education and family life in the development of class identification among the Yoruba. In: Lloyd, P.C. (Ed.), New Elites in Tropical Africa, London: London University Press, pp. 163-183.

23. Lloyd, C.B., 1992. Family and gender issues for population policy. A Paper Presented at the Expert Group Meeting on Population and Women Organised by the Population Division of the Department of Economic and Social Development, New York, UN Secretariat, p . 8.

24. Mader, S.S., 1993. Biology. Brown Publishers, Oxford.

25. Nukunya, G.K., 1992. Tradition and Change in Ghana. Ghana Universities Press, Accra.

26. Nye, I., Berardo F.M., 1973. The Family, Its Structure and Interaction. Macmillan Company, New York, p. 309.

27. Office of The Distribution Engineer, 2001. Ghana Water Company Limited. Kumasi-Ghana.

28. Saunders, R.J., Warford, J.J., 1976. Village Water supply-Economics and Policy in the Developing World. The World Bank, Hopkins University Press, Baltimore/ London, p. 71.

29. SIDA, 1993. Country gender analysis for Tanzania. Prepared for SIDA by Patricia Mbughuni, Tanzania.

30. Sloof, R., 1992. Environmental causes of morbidity and mortality. A Paper Presented at the United Nations Expert GroupMeeting on Population, Environment and Development. Population Division of the Department of International Economic and Social Affairs, UN Secretariat, New York.

31. UN, Economic Commission for Africa, ECA, 1992. Major population-environment problems in Africa. Addis Ababa. Document IESA/P/AC.34/INF.6.

32. UN, 1997. UN Department for Policy Coordination and Sustainable Development, Critical Trends; Global change and sustainable development, New York.

33. UNDP, 1995. Arusha Regional Water Master Plan: Socio- Economic Study.

34. UNICEF, 1991. The situation of women and children in Tanzania: An Overview, DaresSalaam.

35. Verbrugge, L.M., 1979. Female illness rates and illness behaviour: testing hypotheses about sex differences in health. Women and Health 4, 61-79.

36. Water Resources Research Institute, WRRI, 1990. Council for Scientific and Industrial Research. Annual Report, 1995, Accra, p. 10. 